\title{
ADVENT OF AUTO-AFFECTION: POSSIBILITY, GIVENNESS AND RECEPTION IN JEAN-LUC MARION*
}

V I R G I L W. B R O W E

\begin{abstract}
Jean-Luc Marion obliquely suggests that we return to religion when we think through and struggle with those topics that philosophy excludes or subjugates. This paper investigates a selection of such subjugated motifs. Marion's recent claim (perhaps even 'principle'): "auto-affection alone makes possible hetero-affection," will be examined through piecemeal influences made upon its development through Marion's return to religious thinking beyond the delimited jurisdiction of philosophy. Although still proper to the philosophies of Descartes, Kant, and Husserl, Marion finds new insights by tracing their legacy back further to the Christian gospels, Augustine, Aquinas, and, importantly, Nicholas of Cusa. Philosophy, proper, (if there is such a thing) may well adumbrate human understanding of data, phenomena, and possibility by discouraging any further thinking of them in terms of love, givenness, or revelation. It is by preferentially opting for these themes that philosophy excludes or subjugates that makes possible the entanglement of truth with love, suggested by Marion: "truths that one knows only if one loves them first."
\end{abstract}

\section{Key words}

Revelation; Phenomenology; Onto-theology; Nicholas of Cusa; Affect theory

DOI: $10.14712 / 23363398.2019 .4$

* "This study is a part of the research project "Christianity after Christendom: Paradoxes of Theological Turns in Contemporary Culture," Univerzita Karlova, Praha, PRIMUS/ HUM/23. 
I seemed to believe ... I didn't know why.

Something in me seemed to believe ... - my consciousness, as you may say; but my reason didn't.

$\sim$ Mark Twain ${ }^{1}$

$\mathrm{W}_{\mathrm{h}}$

hen considering a return ${ }^{2}$ to religion in the works of Marion, one might first recall a brief comment he makes regarding what religion has become and what its field of study comes to include. "The field of religion could be defined simply as whatever philosophy excludes or at best subjugates." ${ }^{3}$ It is important to note that Marion's openness to religion (and questions ascribed to its study) discloses a nearly inescapable preferential option for the excluded. Phenomenology, too, "feels compelled to address itself directly to the oppressed" and subjugated. It would ally itself with praxes akin to the social gospel and might merit due consideration by anyone believing that, today, "every theologian must adopt a liberation theology" "This facet of phenomenology's potency (or promise) to comingle with liberation theologies has yet to blossom and further develop.

By adopting questions that philosophy debases or excludes from its proper delimited field of study, religion might thereby become a field of engagement with the canonical failures of philosophy (though not only its failures). Marion is very interested in failure. "Failure speaks, in its own way ... failure remains as provisional as it is serious." ${ }^{6}$ One can learn this from Paul and what "reveals" (itself) "as folly." For Marion,

1 Mark Twain, A Connecticut Yankee in King Arthur's Court (Berkeley: University of California Press, 1983), 16; [Chap. 2].

2 Cf. Jean-Luc Marion, Phenomenology and the 'Theological Turn': The French Debate (New York: Fordham University Press, 2000); Hent de Vries, Philosophy and the Turn to Religion (Baltimore: The Johns Hopkins University Press, 1999).

3 Jean-Luc Marion, The Visible and the Revealed, trans. C. M. Gschwandtner (New York: Fordham University Press, 2008), 18.

4 Gustavo Gutiérrez, A Theology of Liberation, trans. C. Inda and J. Eagleson (Maryknoll, NY: Orbis, 1988), 67. Cf. Thesis 5 in Jürgen Moltmann, Religion, Revolution, and the Future, trans. M. D. Meeks (New York: Scribner, 1969), 140.

5 Clodovis Boff, "Epistemology and Method of the Theology of Liberation", trans. R. R. Barr, in Mysterium Liberationis: Fundamental Concepts of Liberation Theology, eds. I. Ellacuría and J. Sobrino (Maryknoll, NY: Orbis Books, 1993), 57-85 [citation, $61]$.

6 Jean-Luc Marion, The Idol and the Distance, trans. T. A. Carlson (Fordham: Fordham University Press, 2001), 26.

7 Jean-Luc Marion, God without Being, trans. T. A. Carlson (Chicago: University of Chicago Press, 1991), 52. 
Kant, for example, "is the thinker of the intuitive shortage of the common phenomenon," "that is to say: the failures of intuition. If philosophy's conceptualizations of motifs are lacking or wanting, we are, then encouraged - perhaps even sanctioned - by Marion to return to them. In doing so, one likely finds oneself within the realm and scope of religion. In what follows, I shall try to address a few such motifs: impossibility, givenness, and reception, all of which are entangled with one another. Religion is no stranger to these phenomena and has, perhaps, always already laid claim to them under different names (e.g., miracle, grace, creation, or advent).

There are oblique indications in Marion that would advocate the systematic or specialized study of religion, religious studies, or theology. A lamentable lack of rigorous theologians and serious scholars of religious phenomena in the public sphere becomes indicative of the "Cartesian doctrine of the unity of the sciences [into a] single 'human wisdom' taken as 'universal"' 9 that grows into modern scientism and positivism, of which Marion believes "religion" to be one of the "principal victims" (in addition to "ethics and philosophy"). ${ }^{10}$ He suggests that the construct of the public intellectual is an epiphenomenal byproduct of the overarching metaphysics he so tirelessly critiques throughout his works. This aspect of metaphysics is based on naïve presumptions of the "universality of knowledge"11 that results in a "model of the "intellectual' [that] can only last in a strictly metaphysical scheme." 12 This accounts for an intellectual climate from which "a great many physicists, astrophysicists, or biologists believe themselves authorized to deal authoritatively" with themes such as god, faith, and religion. ${ }^{13}$

8 Marion, The Visible and the Revealed, 32.

9 Jean-Luc Marion, Believing in Order to See: On the Rationality of Revelation and the Irrationality of Some Believers, trans. C. M. Geschwandtner (New York: Fordham University Press, 2017), 66.

10 Ibid.

11 Ibid., 67.

12 Ibid.

13 Ibid., 66. An exemplary performative of Marion's point, here, can be found in the vitriolic backlash received by Adam Kotsko, a well-informed and outspoken critic of religious phenomena in the public sphere (who yet holds a Ph.D. in theology) from his Twitter post on 20 August 2018, 5:44 PM, criticizing the political commentary of a popular astrophysicist: "I dare you to read Neil deGrasse Tyson's attempts at political commentary and tell me we need more focus on STEM and less on humanities." The more vicious responses thrust upon Kotsko are grounded upon the very kind of universal scientific authority presumed beyond question and critiqued by Marion. This breed of popularity is invested with a kind of "publicity, beyond its current usage" 
Nobody seems more confident to caricature, deride, and dismiss religious phenomena than those who do not go to the trouble to seriously study it. The caliber of argumentation in popular texts produced for mass consumption with incendiary - i.e., marketable - titles (e.g., by Dawkins ${ }^{14}$ or Hitchens ${ }^{15}$ ) pales in comparison to the intellectual rigor of an Augustine, Luther, Barth, or even Weber. ${ }^{16}$ There are of course serious reasons to be suspicious of the hubris or bullying of unquestioned authority and the crippling intellectual effects of what Russell calls "the evils of specialization." 17 There remain, nevertheless, equally serious

critiqued by Marion in his studies on painting. Be it dissemination by either televisuality or social media, such publicity constitutes a public image of the 'intellectual' "always available for transmission, broadcast, and consumption by the viewers." JeanLuc Marion, The Crossing of the Visible, trans. J. Smith (Stanford: University Press, 2004), 52. Cf. Cornel West's critique of the "televisual style" that can become "too preoccupied with TV cameras [and] relies on charisma at the expense of grassroots organizing [or] programmatic follow-through." As such, it "downplays people's participatory possibilities ... More pointedly, it shuns democratic accountability." The Ethical Dimensions of Marxist Thought (New York: Monthly Review Press, 1991), xxxiii.

14 Richard Dawkins, The God Delusion (Boston: Houghton Mifflin, 2006).

15 Christopher Hitchens, God is Not Great: How Religion Poisons Everything (New York: Grand Central, 2007).

16 Far from colloquial socio-scientific dismissal of theology, Weber explicitly expected the most "fruitful and instructive" critiques of his own work to come not from historians or sociologists, but rather from theologians. "We [sociologists] must also investigate thoroughly the beginnings of similar developments in the Middle Ages and early Christianity... which will certainly require very intensive collaboration with theologians" (italics added). It was "a great cause of satisfaction" to Weber that his "forays into" the Protestant ethic were "not received ... with either complete indifference or hostility" by "a number of reputable theological colleagues." He intimates a preference for collaboration with theologians rather than properly disenchanted historians that might become overly positivist. "I completely understand that to them [theologians] this way of relating certain series of religious motivations to their consequences for civil life must appear not to do justice to the ultimate value content of the forms of religiosity in question - since from the standpoint of religious value-judgement, these motivations are coarse and external, peripheral to true religious contents for the inwardly religious nature. And indeed, they are right. However, such merely 'sociological' work must also be carried out - as it has been done by some of the theologians themselves ... It should surely be done best by the specialists, to whom we outsiders [i.e., sociologists] can just here and there offer possible perspectives on the problem, in our way and from our own viewpoint, whether they greet us with approval and interest or not. This was what I had hoped to achieve, and it is from quarters such as these [i.e., theology and theologians] that I expected fruitful and instructive criticism to come - not from part-timer, dilettante, bungling wranglers such as Rachfahl [one of his historian critics]." The Protestant Ethic Debate: Max Weber's Replies to His Critics, 1907-1910, trans. A. Harrington and M. Shields (Liverpool: University Press, 2001), 118; 131-132, fn. 30.

17 Bertrand Russell, History of Western Philosophy (New York: Routledge Classics, 2004), 165. 
incentives to remember that the informal logical fallacy, argumentum ad verecundiam, ${ }^{18}$ is not simply a blanket condemnation of all arguments from authority, but rather of arguments appealing to illegitimate or inappropriate authority (i.e., argumentation posturing as authoritative; basing a conclusion exclusively and only on such authority without any due evidentiary support for logical inference).

Marion's rigorous criticism of Kantian metaphysics ${ }^{19}$ does not silence the call for a certain logical deontology. There remains, nonetheless, a "duty to argue" ${ }^{20}$ for the sake of religion since Marion believes religion "has to a large extent lost the battle of intelligence," because it waged "an intellectual battle without using intellectual means." 1 Therefore, the vocation of the religious thinker (or simply, "the baptized") is to "convince argumentatively," transforming "the kerygma into arguments ... usable in public debate."22 This includes, of course, the ruthless socio-political criticism of the history of ecumenical religion. ${ }^{25}$ If Marion's philosophy does not seem churchy enough (or refraining from direct engagement with any systematic ecclesiology), it

18 When Locke coins the name of this fallacy in Book 4, Chapter 17, ๆ19 of An Essay Concerning Human Understanding, he warns his readers against the mistake of presupposing the same degree of due deference, logical validity, or cognitive significance be necessarily given to the mere "opinions" of an expert or scholar whose "learning ... in some other cause [or field of study that] ... has gained a name, and settled their reputation in the common esteem" as that legitimately deserved be given to an "approved" "authority" of another cause or field of study in which the former is not truly trained or learned. In line with Locke, Marion is simply and similarly warning his readers against the mere opinions (i.e., of "physicists, astrophysicists, or biologists," though well-trained, learned, and authoritative in those fields) when they are uncritically presumed to carry the same authority or veracity in areas outside those fields and, in Locke's words, fallaciously "put ... in the [equal] balance against that of some learned doctor" (in, e.g., religious studies or theology), that ought "to be received with respect," when grappling with singular questions of god, grace, faith, etc. John Locke, An Essay Concerning Human Understandin, Vol. 2 (New York: Dover 1959), 410; italics added.

Cf. Christina M. Geschwandtner, Degrees of Givenness: On Saturation in Jean-Luc Marion (Bloomington: Indiana University Press, 2014), 24; 34-35; 71-73. Robyn Horner, Jean-Luc Marion: A Theo-Logical Introduction (Burlington, VT: Ashgate, 2005), 20; 113-114; 131-132; Jason Alvis, "Subject and Time: Jean-Luc Marion's Alteration of Kantian Subjectivity," Journal of Cultural and Religious Theory 14, no. 1 (2014): 25-37.

20 Marion, Believing in Order to See, 74 (perhaps akin to Robyn Horner's "Postmodern Imperatives," 35-46).

21 Ibid., 73.

22 Ibid., 75.

25 "There is certainly nothing scandalous," for Marion, "about criticizing the Church and every Christian can denounce the Church's sins." Ibid., 70. 
is perhaps simply because he believes that "the baptized do not think of the Church, [in its colloquial or ecclesial valences] because they [instead] live in it and, in this setting, see Christ." ${ }^{24}$ There is, perhaps, a crypto-pragmatism lurking within this phenomenological approach to thinking.

When grappling with a return of (or to) religion, one must keep in mind the kind of recourse to religiousness or religiosity that Marion overtly discourages. He is ever critical of metaphysical absolutism (and metaphysics, in general) and warns his readers of the "desperate ambition" behind the "triumphant return of the preeminent metaphysical attempt at absolute knowledge, with all the illusions and dangers to which history so clearly attests," that might "be an irrational exaltation ... reviving the fantasies of ... "mystical' intuition." 25 For Marion, "we no longer belong to the dogmatic epoch of metaphysics; [rather,] we inhabit the era of nihilism ..."26 Though he is not afraid to engage thinkers often considered to be mystics (e.g., Pseudo-Dionysus, Scotus, Bernard, etc.), he yet insists on the the dangerous illusions and fantasies of irrationality and mysticism.

It is in these ways that some aspects of Marion's philosophy might be considered returns to religion. They endeavor to develop and improve upon some of philosophy's perjuries, failures or subjugations. In doing so, Marion always endeavors to avoid any illusory irrationality of metaphysics, mysticisms, and dogmatisms. If such avoidance is possible, it must refuse attempting to complete or perfect philosophy's failures by way of philosophy's own delimited methods and adumbrated terms. One may never escape the irrational or mystical, if one claims, "to surpass and complete ... affirmative certainty by another affirmative, definitive, and dogmatic certainty." 27 One alternative to this particular example, Marion develops as negative certitude, which he believes to

\footnotetext{
Ibid., 70-71.

25 Jean-Luc Marion, Negative Certainties, trans. S. E. Lewis (Chicago: University Press, 2015), 5; italics added. Elsewhere, he writes, "The saturated phenomenon must not be understood as ... a 'mystical' case of phenomenality." The Visible and the Revealed, 45.

26 Marion, The Crossing of the Visible, 80. This alleged era of nihilism is perhaps a postmetaphysical one in which, in the words of Jan Patočka, 'god' is "no longer accepted as an explanatory concept." The Natural World as a Philosophical Problem, trans. E. Abrams (Evanston: Northwestern University Press, 2016), 6.

27 Marion, Negative Certainties, 5.
} 
be a path found within philosophy, itself, (though perhaps subjugated by it) ${ }^{28}$ but can yet be discerned, specifically, in Descartes and Kant. Although Marion emphasizes Descartes and Kant (and eventually Husserl) as the philosophical precursors of negative certitude, one can, arguably, trace a thread to them from Marion, himself, through valences of 'nullity' or 'negativity' in Heidegger; and, further, to the negation and negative dialectics of Hegel; and, still further, back to the coincidentia oppositorum of Nicholas and the birthpangs of negative theology ${ }^{29}$ (e.g., learned ignorance). Though Heidegger is a primary interlocutor throughout Marion works, Hegel receives less direct attention. It is as if Marion almost sidesteps Hegel altogether by appealing directly to Nicholas, who seems to be (even if only unconsciously osmosed through Bruno $)^{30}$ one of Hegel's under-appreciated intellectual precursors. ${ }^{31}$

28 In the terms laid out a decade earlier in The Visible and the Revealed (as 'religion.')

29 Marion "had been impressed for a long time by ... 'negative theology' especially since leading a seminar of The Divine Names at Montmarte. The conceptual possibilities, which one right away sensed to be powerful in it, intrigued [him] especially." JeanLuc Marion, The Rigor of Things, trans. C.M. Geschwandtner (New York: Fordham University Press, 2017), 107.

30 It is quite striking that Hegel never addresses Nicholas throughout the (otherwise) encyclopedic breadth of his writings and system. Yet, consider Hegel's account of Giordano Bruno's "unity of opposites" in Lectures on the History of Philosophy, Vol. 3, Medieval and Modern Philosophy, trans. E.S. Haldane and F.H. Simson (Lincoln: University of Nebraska Press, 1995), 133; [Pt. 2, \$3.B.3.ع], keeping in mind Bruno's confessed indebtedness to Nicholas in Dialogue 5 of De la causa, principio e uno: "Is there anything more opposite to a straight line than a curve? And yet, they coincide in the principle and the minimum, since (as the Cusan, the inventor of geometry's most beautiful secrets, divinely pointed out) what difference could you find between the minimum and the minimum cord? ... We must, therefore, say and believe with absolute certainty that ... [t]he infinite straight line thus finally becomes the infinite circle." Cause, Principle and Unity and Essays on Magic, trans. R.J. Blackwell (Cambridge: University Press), 96-7; italics added. Q.v., Leo Catana, "The Coincidence of Opposites: Cusanian and Non-Cusanian Interpretations in the Thought of Bruno," Bruniana \& Campanelliana 17, no. 2 (2011): 381-400.

31 The Argentinian political philosopher, Ernesto Laclau, used to joke in his seminars that the dialectic had been discovered in Cusa a millennium before Hegel. He writes that a "discourse of radical emancipation emerged for the first time with Christianity ... a tradition which, passing through Northern mysticism, Nicholas Cusanus and Spinoza, would reach its highest point in Hegel and Marx." Emancipation(s) (New York: Verso, 1996), 9. Although, like Hegel, he nearly never addresses Nicholas directly by name, Thomas J. J. Altizer repeatedly implies this legacy in innumerable discussions of coincidentia oppositorum, which he believes to be "unquestionably a primal ground of Western Christendom as a whole." History as Apocalypse (Albany: State University of New York Press, 1985), 63. Q.v., the compelling case offered by Thora I. Bayer, "Nicholas of Cusa's Maximum as a Renaissance Precursor to Hegel's True Infinity in Advance," Idealistic Studies 45, no. 3 (2015): 339-354. 
The alternative to metaphysical philosophy and mystical dogmatism (which would include fundamentalist religion) that Marion offers, then, would be a particular kind of philosophy of religion practiced as phenomenology of religion and, thereby, "a truly radical phenomenology." 32 This is not because Marion presumes that "as if by right ... the phenomenological method [is] in any way particularly suitable for religion." ${ }^{35}$ Phenomenology seems no better suited to religion than to, say, probability statistics. But if philosophy's most troublesome issues become sublimated or deferred to religion (wittingly or not), then religion "could offer a possible field for phenomenology," ${ }^{34}$ but only if phenomenology makes manifest phenomena that would have remained distorted, undiscovered, or ever missing without it. It is in this way that Marion allies himself with philosophy before religion and always seems to give philosophy - or, at least, phenomenology - the last word. ${ }^{35}$ This focus upon the manifestations of phenomena discloses Marion's philosophy to be, at its core, a philosophy of revelation, the hallmark of which is his singular phenomenological readings of pre-modern sources (pre-Kantian/pre-Husserlian) colloquially considered religious and, specifically, Christian: e.g., the gospels and Nicholas.

One of the primal ways by which philosophy approaches the themes of possibility and impossibility is when attesting to the epistemological limits of human understanding. The scope of human cognition and experience allows for a certain extent of knowability or knowledge of things and phenomena (as possible) while other things or phenomena are simply beyond the delimited capacity of human understanding and are, hence, categorized as impossible or impossibilities. There is almost nothing more signature for Enlightenment philosophy than to mark, attest, and grapple with what is impossible for humans to think, know, or experience. Be it by Descartes, Hume, Kant, or Husserl, philosophy ever acquiesces the limits of possibilities for human understanding. As canonical categories burrowed within epistemology, possibility and impossibility open themselves to new considerations, for

\footnotetext{
Marion, The Visible and the Revealed, 36.

Ibid., 1.

Ibid.

35 E.g., he states that "the sacramentality of the sacrament, undoubtedly belongs first of all to theology." But since "any sacrament ... is a matter of rendering visible ... invisible grace [... then ...] theological reflection cannot get by without a strictly phenomenological analysis." Marion, Believing in Order to See, 102-103.
} 
Marion, of revelation (or, perhaps what Heidegger calls, Offenbarkeit; 'revealability').

This is arguably an unlikely Lukan legacy. On this point, Marion's phenomenological engagement with religion finds itself - almost by necessity - confronting "the difficult narrative of the Annunciation," ${ }^{6} 6$ in the same essay by which he, also, addresses an uncanny inversion of the ontological argument for the existence of god set in motion by Nicholas. Mary proclaims precisely her epistemological limits and, by consequence, a "factual impossibility," 37 in confessing what she cannot and does not know to angelic authority. "I know no man [äv $\delta \rho \alpha$ ov

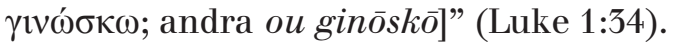

Marion reads the angelic response as an assertion of "the principle of radical possibility." ${ }^{38}$ On god's part "no word [or saying; rhēma] shall be impossible" (Luke 1:37). To believe this word of radical possibility is to recognize the epistemological limitations and impossibilities of one's human perspective "in order to pass over to" 39 the radical possibility of god's perspective (for which nothing shall be impossible). Later in Luke, one reads, "What is impossible with men is possible with God" (18:27; cf. Matthew 19:26 and Mark 10:27).

Both philosophy - whether as metaphysics or epistemology - and even revealed religion eventually concede, in one way or another, that the impossible is "the concept above all concepts" 40 that determines what humans cannot know ... but which even philosophy, nevertheless, still calls - or names - 'god.'41 As such, impossibility "defines the proper place of the question of God." ${ }^{\prime 2}$ (This would be also the case for

36 Jean-Luc Marion, “The Impossible for Man - God", trans. A Davenport, in: Transcendence and Beyond, eds. J. D. Caputo and M. J. Scanlon (Bloomington: Indiana University Press, 2007), 33 [\$8].

37 Ibid., 34.

38 Ibid.

39 Ibid.

40 Ibid., 26; [\$5].

41 "Three standpoints ... - namely metaphysics, philosophy... and Revelation - thus agree at least on this one point: The impossible ... designates what we know only by name - God." Marion, ibid., i.e., "that mystery we too casually call 'God”": Craig Keen, After Crucifixion: The Promise of Theology (Eugene, OR: Cascade Books, 20), 80. Cf. Karl Barth, The Resurrection of the Dead, trans. H. J. Stenning (London: Hodder and Stoughton, 1933), 206; The Epistle to the Romans, trans. E. C. Hoskyns, sixth ed. (New York: Oxford University Press, 1968), 44.

42 Marion, "The Impossible for Man - God," 26. 
unknowability. Religious thinkers, therefore, are called and tasked to remain "guardians of the unknowable." ${ }^{43}$

These lines from the gospel of Luke seem to motivate Nicholas to formulate one of Marion's preferred paradoxes. Nicholas writes: “... as nothing is impossible with God, we must, by means of what is impossible in the world, raise ourselves to contemplate God, with whom impossibility is necessity." ${ }^{44}$ With a few theoretical gymnastics - which could perhaps only come about by negative certitude - Marion finds, here, in Nicholas not simply a straightforward ontological argument for the existence of god; e.g., the possibility of god's existence (colloquially attributed to or associated with Anselm or Descartes). With textual motifs firmly rooted in all the synoptic gospels (as opposed to Aristotle, in which Hegel's philosophy is determined and rooted), in proclaiming impossibility as necessity, Nicholas discovers and performs a kind of proto-phenomenological deduction (or "reduction," epokhê) ${ }^{45}$ centuries before its time. Nicholas not only anticipates the negative dialectics of Hegel, but the transcendental deduction of Kant and even the phenomenological reduction of Husserl. Such a genealogy is exemplary of the kind of incipient return of religion to which thinking must attend. Reduction and givenness go hand in hand and are indissociable from one another. ${ }^{46}$

In Cusa one finds 'god' to be that to which there is no possibility of impossibility. Nothing can make god, godself, impossible. It is upon human conception, alone, that the impossible can impose itself (i.e., on our faculties, hard-wiring, experiential data-collection, sensation, and understanding). This aspect of early 'negative theology' comes to further develop into what is often referred to as 'dialectical theology'

43 Marion, Believing in Order to See, 83.

44 Nicholas of Cusa, Trialogus de possest, Werke, Vol. 2, ed. P Wilpert (Berlin, 1967), 66, quoted in Marion, "The Impossible for Man - God," in Transcendence and Beyond, 40, fn. 26; italics added.

45 "[T]he reduction consists in not taking everything I perceive for granted and in not receiving everything that happens to me with the same degree of evidence and thus of certainty but in each case to question what is actually given in order to distinguish it from what is only pieced together, inferred, or, so to say, acquired in a roundabout way, indirectly." Marion, The Rigor of Things, 73-4. Cf. Edmund Husserl, Ideas: General Introduction to Pure Phenomenology, trans. W. R. Boyce Gibson (London: Routledge Classics, 2012), 34; 59-63 [\$18; \$\$32-33].

46 The "second word that one must introduce together with 'reduction,' namely [is] that of 'givenness' [donation]." Marion, The Rigor of Things, 74. 
(usually associated with Nietzsche, Kierkegaard, Barth ${ }^{47}$ or Altizer), based on an infinite qualitative distinction between the eternal and time; god and humanity. Similarly, for Marion, "the grace of Christ ... will never be counted among worldly phenomena." ${ }^{48}$ To think grace, givenness, or god (all of which are entangled and may well be synonyms) as worldly phenomena suited to human reason and cognition becomes, for Marion, a practice of idolatry. Insisting on this kind of qualitative distinction would be another way by which Marion warns against certain metaphysical forms of religion in which it is either effaced or forgotten. He warns that "we must resist the illusion of the theologians and alleged Christian exegetes," 49 if they believe humanity sets its itself up as the master of the gospel and the word of god as interpreter and judge. ${ }^{50}$

The difference between the possible and the impossible always already eliminates any possible categorical confusion between humanity and god. Further, this paradox of impossible necessity stands the stereotypical ontological argument on its head. Nicholas' reading of the gospels "no longer proves God's existence, but [rather] the impossibility of [god's] impossibility" 51 and, thereby, god's possibility. "The necessity of God's possibility flows from the impossibility of his impossibility." 52

Any further inference of the existence of god (if there is such a thing) becomes an indirect or collateral epiphenomenon. It is not a primary concern. In fact, to forcefully insist that the category of existence be applicable to god may well be but an idolatrous illusion of onto-theologians, as put forth in Marion's breakthrough text, God without Being. God cannot be conceptualized, as such, which is why Marion advocates a kind of conceptual atheism. ${ }^{53}$

47 With regard to Barth, cf. Marion, Discours de réception de Jean-Luc Marion à l'Académie français et réponse de Mgr Claude Dagens (Paris: Bernard Grasset, 2010), 39. Q.v., Marion's discussion of the lack of such distinction in the critique of Feuerbach. God without Being, 16.

Marion, Believing in Order to See, 104-105.

49 "...il faut résister à l'illusion des théologiens ou des exégètes supposés chrétiens." Marion, Discours de reception de Jean-Luc Marion, 20; translation mine.

50 This is Marion citing Jean-Larie Lustiger, French Cardinal of the Roman Catholic Church and Archbishop of Paris (until 2005), with whom he is in agreement (on this particular point): "hypothèse que le maître de l'Évangile, le maître de la Parole de Dieu n'[est] pas Dieu, mais l'homme s'érigeant en interprète, en juge ...” Ibid., 21.

51 Marion, "The Impossible for Man - God," 28.

52 Ibid., 29.

53 Marion, God without Being, 16. 
Nicholas is iterating the principle of radical possibility that Marion finds the angel revealing to Mary. This would be one of the many points on which Marion resists Hegel through an appeal to Nicholas, and by doing so, further resists the temptation of ontotheology he suspects and detects in Hegel. He finds Hegel insisting on "the equivalence of thought and Being ... posited as a fundamental metaphysical thesis." ${ }^{54}$ This applies not only to the cogito or I (of 'I think therefore I am'), but also to god. ${ }^{55}$ This congenital Cartesian proclivity of ontotheology survives into Hegel's system. ${ }^{56}$

The impossibility of god's impossibility is indicative of the innumerable and immeasurable ways by which delimited human intuition and understanding is yet permeated, at all times, by an excess of givenness. Such occurrences, happenings, truths, or phenomena comprise the givenness in which the quotidian minutiae and banality of our everyday lives is "saturated," (to use an almost clinical term of Marion; it is a "saturated phenomenon"). Givenness and reception go hand in hand, since there is no "greater crime for a phenomenologist than ... not accepting [or receiving] what one sees [or experiences]. ${ }^{957}$ For Marion, "givenness alone indicates that a phenomenon ensures in a single gesture both its visibility and the full right of that visibility, both its

54 Marion, On Descartes' Metaphysical Prism: The Contribution and Limits of OntoTheology in Cartesian Thought (trans. J. L. Kosky). Chicago: University Press, 1999, $206[\$ 16]$.

55 Marion finds the "theoretical decision [by which Descartes] metaphysically institutes the $e$ go [also] metaphysically enthrones god." Ibid.

56 Marion finds Hegel complicit in at least "one of the two Cartesian onto-theologies [i.e., either of the ego or god] considered as an entity that thinks first of all itself before any other." Marion, "Thomas Aquinas and Onto-theo-logy", trans. B Gendreau, R. Rethy, and M. Sweeney, in Mystics: Presence and Aporia, eds. M. Kessler and C. Sheppard (Chicago: University Press, 2007), 41-42. Here, with the ego/god that first thinks itself before all others, one begins to appreciate the phenomenal importance of Marion's interest in developing an experience of "auto-affection" beyond the ontotheology of either god or ego thinking-itself. If there is a point of contact between Hegel and Marion worth developing, it is perhaps on the phenomenon or experience of recognition (a word that means two very different things to these two very different thinkers). "Knowing without demoting into an object would imply knowing what no mind masters, organizes, or produces; cognizing without mistaking could be called recognizing. Recognizing a human feature that would not straightaway be subject to us ... but instead received it as a gift." Marion, Believing in Order to See, 81; italics mine. Q.v., 84. Reception, as such, would be "when one recognizes [the saturated phenomenon] without confusing it with other phenomena." Marion, The Visible and the Revealed, 41.

${ }_{57}$ Marion, The Visible and the Revealed, 133. 
appearance and the reason for that appearance." ${ }^{58}$ In this way a phenomenology of religion moves beyond the limits of vulgar empiricism and positivism and the phenomenological method becomes well-suited to religious thinking. ${ }^{59}$

Marion's understanding of givenness is rooted in Husserl's principle of principles: "Everything that offers itself to us in originary 'intuition' ... must be received exactly as it gives itself out to be ..." ${ }^{\prime 60}$ Marion reads the principle as a givenness that revalues both reception and auto-affection. ${ }^{61}$ It is not simply by active agency or agential volition that one comprehends or apprehends that which gives-itself. What gives-itself may be passively received, rather than actively taken. An object is " $a c$ tively constituted" by human understanding as it is experienced, but an event is "that which I can only receive." 62 It is because givenness gives, offers, and, as such, auto-affects itself that humans may receive it (and, as such, be auto-affected ${ }^{65}$ by it) in the experience of one's own auto-affection.

58 Ibid., 22; italics added.

59 "[B]y playing on the limits of phenomenality, certain phenomena not only can appear at those limits, but appear even better there" Ibid., 25; italics added.

60 Cited in Marion, Negative Certainties, 202. Cf. Husserl, Ideas, 43-44 [\$24].

61 With regards to the vertiginous complexity of "auto-affection," as such, see Michel Henry, The Essence of Manifestation, trans. G. Etzkorn (The Hague: Martinus Nijhoff, 1973), 186-191 [\$24]. Q.v., Henry, Philosophy and Phenomenology of the Body, trans. G. Etzkorn (The Hague: Martinus Nijhoff, 1975), 41; Giorgio Agamben, Remnants of Auschwitz: The Witness and the Archive, trans. D. Heller-Roazen (New York: Zone Books, 1999), 109-110; Virgil W. Brower, "Jacques Derrida" in Agamben's Philosophical Lineage, eds. A. Kotsko and C. Salzani (Edinburgh: University Press, 2017), 234-237.

62 Marion, Negative Certainties, 181; italics added.

63 The difficulty (if not impossibility) of trying to attend to a simultaneous activity and passivity of one and the same phenomenon is expressed - however inadequate, awkward, or confusing - by emphasizing the "auto-" of the former and the "-affection" of the latter. An Auto-affection is auto-affection (which is why and how auto-affection makes possible hetero-affection[s]). This borrows from Heidegger's perhaps equally questionable style to express that an abyss ( $A b$-grund) is yet still a kind of grounding or ground (Ab-grund) when he writes, "Der Ab-grund ist Ab-grund." Martin Heidegger, Beiträge zur Philosophie (Vom Ereignis), ed. F. W. Herrmann (Frankfurt am Main: Klostermann Verlag, 1994), 379. Under comparable influence of Husserl's principle of principles, it is worth considering that Heidegger attempts to intimate these two distinct yet simultaneous valences of experience in his analysis of the epistles of Paul of Tarsus: "Experience' designates: (1) the experiencing activity, (2) that which is experienced through this activity. However, we use the word ['experience'] in its double sense, because it is precisely the fact that the experiencing self and what is experienced are not torn apart like things [...] that expresses what is essential in factical life experience ... It has both a passive and active sense." The Phenomenology of Religious Life, trans. M. F. and J. A. Gosetti-Ferencei (Bloomington: Indiana University Press, 2004), 7 [\$ 3]; italics added. 
It is because, on the one hand, [a] givenness (grace or god) is beyond human intuition (lacks and has no need for human intuition) and because [b] humans, on the other hand, experience only by virtue of their intuition, that Marion can claim: "nothing gives itself if not in or through intuition." ${ }^{64}$ This means that what impossibility, unknowability, givenness, and reception might teach human comprehension is: no givenness gives-itself (no god gods; no grace graces; no advent advenes; no revelation reveals) except to the experiences of humanity, despite their shortcomings. Humanity, as such, finds itself beyond objectification or thinghood. This makes possible what is arguably Marion's reformulation of Husserl's principle of principles into the language of affectivity: "auto-affection alone makes possible hetero-affection." ${ }^{\circ}$

This is specifically formulated by Marion in his most poetic text, endeavoring to respond and attend to the dizzying phenomena of love. Love makes possible new kinds of knowledges. It would be because givenness gives-itself (activating affectivity) by which one may experience oneself in reception of it (as passive auto-affection) that one can, then (in and because of the experience of that very reception), experience others as hetero-affection (in ways that the 'I,' ego, or cogito could never accomplish, alone, of its own volition and thinking-itself). The givenness of such otherness would be discoverable and revealed in diffuse experiences; experiences of one's neighbor, beloved, time, future, death, and even - perhaps, only - god, godself.

Protestant Theological Faculty, Charles University Černá 9

11555 Praha 1 Czech Republic E-mail:virgil@u.northwestern.edu

64 Marion, Negative Certainties, 203.

65 Jean-Luc Marion, The Erotic Phenomenon, trans. S. E. Lewis (Chicago: University Press, 2007), 114; italics added. 